UDC 678.664

\author{
V.N. Anisimov, V.V. Anisimov
}

\title{
TECHNOLOGICAL FEATURES OF PROCESSING LINEAR BLOCK-POLYURETHANES OF DIFFERENT MORPHOLOGY
}

\author{
Ukrainian State University of Chemical Technology, Dnipro, Ukraine
}

\begin{abstract}
We showed the inability to evaluate the properties and the processing conditions of polyurethanes based of their hardness, although such evaluation is usually used in their marking, this approach does not take into account the peculiarities of molecular structure and the nature of the initial components. A scientifically substantiated approach to the creation of materials based on block-polyurethanes (BPU) of different morphology was developed. The effect of rigid phase content was studied. The characteristic points of the rigid blocks content, $\mathrm{P}_{\mathrm{c} 1}$ and $\mathrm{P}_{\mathrm{c} 2}$, which correspond to the conditions of geometric phase transitions, were determined and the conditions of the formation of geometric phase morphology with optimal parameters $\left(\mathrm{P}_{\mathrm{cl}} \leq \mathrm{P}_{\mathrm{c}} \leq \mathrm{P}_{\mathrm{c} 2}\right)$ were found. Thus, there is a noticeable inflection in all of these graphic dependences for the BPU based on oligo(tetramethylene ether) glycol at points with $\mathrm{P}_{\mathrm{cl}}=30 \%$ and $\mathrm{P}_{\mathrm{c} 2}=50 \%$ (conditional strength at tension, elasticity modulus, relative elongation at rupture, hardness, softening temperature, and degree of crystallinity). The technological parameters of BPU molding under pressure with optimal phase morphology, including rapid prototyping complexes (3D printers), have been established. The recommended parameters allowed productively affecting the process of molding under pressure and preparing qualitative products from the developed composites with a specified complex of properties (gaskets, friction supports, elastic elements of gearing devices, extruded strands, circular rings, plates, tubes, etc.). In addition, due to recycling, we managed to substantially reduce ecological risk and increase the commercial attractiveness.
\end{abstract}

Keywords: block-polyurethane, hard block content, molding under pressure, technological process, temperature regime.

DOI: $10.32434 / 0321-4095-2019-125-4-5-11$

\section{Introduction}

The search for polymeric materials with universal properties, which combine the property complexes of elastomers and plastics, has become an impulse to the synthesis in the 1940s of a new class of high-molecular compounds, polyurethanes. Now, there are elastic, semi hard and hard materials produced on the basis of polyurethanes. Polyurethanes are processed by practically all available technological methods: pressing, extrusion and molding. Filled, reinforced, foamed, laminated products in the form of plates, sheets, blocks, profiles and fibers can be obtained from polyurethanes [1].

For fifty years since the beginning of the industrial production of polyurethanes, need for them increased and now reached world volume 17.65 million tons $(33.7 \%$ of the world's volume is made in People's Republic of China).

Recently, thermoplastic materials based on linear block-polyurethanes [2] are increasingly used. Indifference to oil products, high wear resistance, the ability to be processed into products at high speed and high-automation equipment, possibility of multiple recycling, the absence of waste products during production and elimination of the vulcanization stage are the main advantages of linear block-polyurethanes (BPU). An ability to change the ratio of the original components allows varying the BPU properties in a wide range and, consequently, achieving purposefully approach in the creation of polymer systems with preset properties. Hardness is usually considered as a main parameter of the change in physical-mechanical properties and is a basis of the marking. However, it does not take 
into account peculiarities of the molecular structure of polyurethanes and the nature of the original components, which is one of the reasons for the lack of a scientifically grounded technology for the processing of these materials into product.

\section{Experimental}

Linear block-polyurethanes of different molecular structures and morphologies were synthesized. In accordance with modern ideas about the morphology and structure of BPU [3], they are block-copolymers of the form$$
-\left[-\left[-\mathrm{E}_{\delta}-\right]_{\mathrm{n}}-\mathrm{A}_{\mathrm{r}}^{\mathrm{i}}-\left[-\mathrm{B}_{\mathrm{r}}-\mathrm{A}_{\mathrm{r}}^{\mathrm{i}-}\right]_{\mathrm{m}}-\right]_{\mathrm{k}}-
$$

(where $E_{\delta}$ is oligoglycol of different nature, $A_{r}^{i}$ is isocyanate and $B_{r}$ is an extension chain), whose molecules consist of segments of moderately flexible chains with a low glass transition temperature (often called flexible or elastic segments) and polar, relatively hard segments, that are alternating between each other. The composition of the elastic segments includes the elementary chains of oligoeters or oligoesters. Rigid segments are formed as a result of the interaction of diisocyanates with low molecular weight glycols. Due to the limited mutual solubility of the segments in polyurethane, a two-phase structure is formed, the degree of heterogeneity of which can be sufficiently large [4]. This allows us to consider BPU as filled systems, and role of a somewhat filler in which is played by the blocks of hard segments, connected with the main chains of the molecule by chemical bonds and with adjacent molecules by physical transverse bonds. As a result, it can be expected that the change in the ratio of initial components can allow wide range variations in BPU properties, thus, a purposefully approach to the creation of polymer systems with preset properties can be obtained. It is obvious that processing regimes of such materials will be significantly different.

Characteristics of the initial components with their chemical formulae for the synthesis of investigated polyurethane block-copolymers are given in Table 1.

The OOTMG oligoether (TS 6-02-646-81) was prepared as a result of splitting through ether bond of tetrahydrofuran in the presence of alkaline catalysts. The peculiarity of oligoeters is the presence of the macromolecules of the etheric link $\equiv \mathrm{C}-\mathrm{O}-\mathrm{C} \equiv$ in the main chain, which is regularly repeated. BPUs based on oligoether show increased hydrolytic resistance, heat resistance and frost resistance [4].

Oligoesters of different molecular weights were obtained by the interaction of adipic acid with glycols (TS 38-103-582-85). A characteristic feature of the oligoesters is the presence of regularly repeating macromolecules of ester bond $-\mathrm{CO}-\mathrm{O}-$ in the main chain. BPUs based of these glycols exhibit high physical-mechanical properties, good resistance to light and thermo-oxidative destruction and high processing efficiency [4]. The molecular weight of oligoesters varied in the range of 500-2000. Saunders and Freish reported [5] that the usage of oligoglicols in this range of molecular weight is favorable during the synthesis of BPUs. 4,4'-Diphenylmethane diisocyanate (MDI) (TS 113-03-29-3-80) was used as isocyanate, which is the most common during the synthesis of BPUs [6]. Common low-molecular glycol, 1,4-butanediol (BD) (TS 64-5-65-80), was chosen as a chain extension.

To determine elasticity modulus at tension $\left(\mathrm{E}_{\mathrm{p}}\right)$, conditional strength at tension $\left(f_{\mathrm{p}}\right)$, relative elongation $\left(\varepsilon_{\mathrm{p}}\right)$, residual elongation $(\varepsilon)$, coefficient of mechanical hysteresis losses $(\chi)$ and Vicat softening temperature $\left(T_{p}\right)$, standard methods of physical and mechanical tests were used.

The degree of crystallinity $\left(\mathrm{C}_{\mathrm{k}}\right)$ was determined by the Matthews' method as a ratio of the area under the crystalline reflexes $\left(S_{k}\right)$ in the X-ray chart to the total area under the coherent scattering curve $\left(\mathrm{S}_{\mathrm{k}}+\mathrm{S}_{\mathrm{a}}\right)$.

\section{Results and discussions}

Based on the results of previous studies, we established that different ability of the oligoglycol component of BPU, which contains hydroxyl groups, to crystallize, affects the hardness of the material (Fig. 1). In case of amorphous oligoglycol (OG), the hardness of the polyurethane block-copolymers increases in direct proportion to a decrease in the content of components containing hydroxyl groups.

If the BPU contains oligoglycol, which is capable to crystallize, then the hardness has the highest values (95-98 units of Shore A) in the interval of its maximum content. Thus, polyurethanes of the same structure can have either different values of hardness, and, accordingly, values of elasticity, abrasion resistance and coefficient of friction or the same hardness and completely different morphology. If we compare polyurethanes of the same structure but of different molecular weights (for example, 20,000 and 80,000), then we can see that their hardness will differ 2 times (Fig. 2), hence there should be different wear values. Thus, we can conclude that the evaluation of the BPU properties without taking into account the molecular structure is inaccurate, and the proper regimes of processing are not appropriate.

Investigation of the dependence of physicalmechanical properties of BPU on the molecular weight $(\mathrm{M})$, performed by Scholenberg using materials, synthesized on the basis of oligobutylene glycol adipate (OBGA), 4,4'- diphenylmethane 


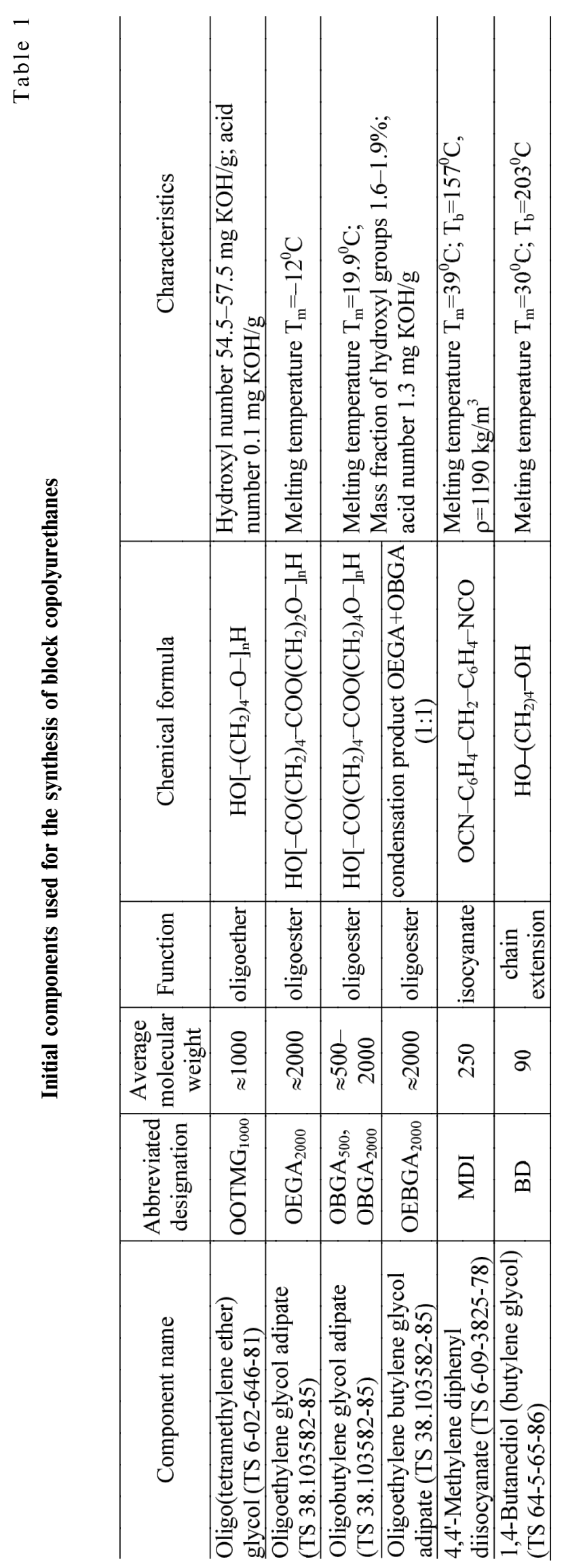

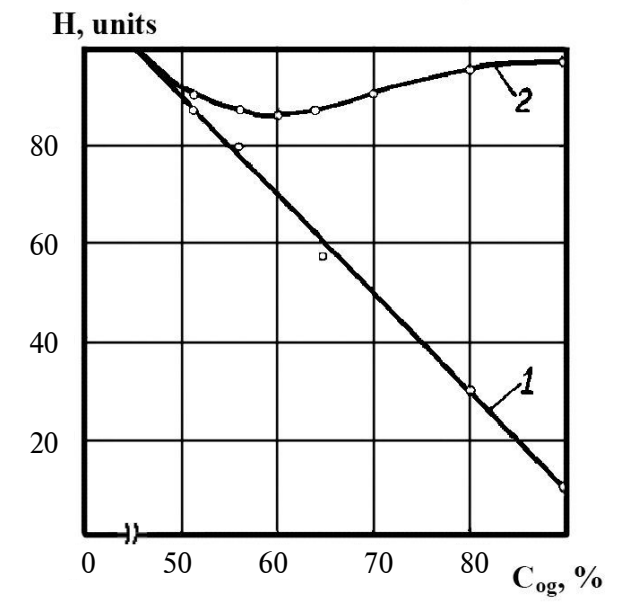

Fig. 1. Influence of crystallinity of oligoglicol component in BPU $\left(\mathrm{C}_{\mathrm{og}}\right)$ on the hardness $(\mathrm{H}): 1-$ amorphous oligoglycol; 2 - crystalline oligoglycol

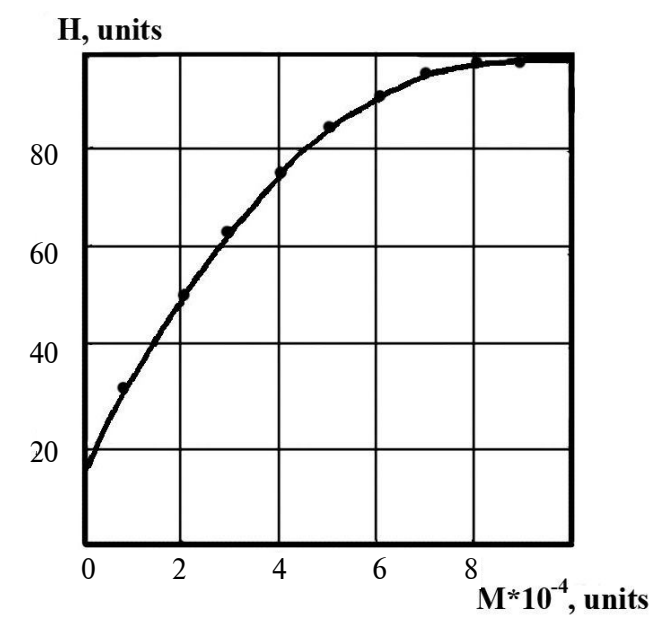

Fig. 2. Influence of molecular weight of BPU (M) on the hardness $(\mathrm{H})$

diisocyanate (MDI) and butanediol (BD), showed that a number of characteristics sharply increases only up to the values of $M=35,000-40,000$, after which their growth stops. These properties include density, conditional stress at elongation, conditional strength at tensile, hardness modulus at torsion and melting temperature. Some indicators, such as Brookfield viscosity and stress relaxation time, were increased in proportion to $\mathrm{M}$, whereas the melt flow rate, relative elongation, bending resistance and conditional stress at $5 \%$ and $30 \%$ elongation were reduced [1].

Previous investigations showed that polyurethane block-copolymers of molecular weight, that corresponds to an index of characteristic viscosity 
$[\eta]=0.8-1.1 \mathrm{dl} / \mathrm{g}$, have the most acceptable structural order and high heat resistance [7]. Therefore, for further research, BPU with molecular weight, that corresponds to index of characteristic viscosity $[\eta]=0.8-1.1 \mathrm{dl} / \mathrm{g}$ is chosen.

The morphological structure was varied by changing the ratio of low-molecular glycol (butanediol) to oligoglycol during synthesis. With an increase in the amount of butanediol, the content of hard blocks $\left(\mathrm{P}_{\mathrm{c}}\right)$ in the block copolyurethanes increses, which is defined as a part of a molecule with a low-molecular diol:

$$
P_{c}=\frac{90 n+250(n+1)}{a \cdot M_{o g}+90 n+250(n+1)} \cdot 100 \%,
$$

where $\mathrm{P}_{\mathrm{c}}$ is the content of hard blocks, $\% ; \mathrm{M}_{\mathrm{og}}$ is the molecular weight of oligoglycol $(500,1000,2000)$; 90 is the molecular weight of low-molecular butandiol; 250 is the molecular weight of diisocyanate; $a$ is the number of moles of oligoglycol; $\mathrm{n}$ is the number of moles of butanediol; and $(\mathrm{n}+1)$ is the number of moles of diisocyanate.

As an example, Figure 3 shows the dependences of physical-mechanical characteristics of BPUs based on OOTMG $\mathrm{O}_{1000}$ on the parameters of the morphological structure.

In case of low $\mathrm{P}_{\mathrm{c}}$ values (up to $30 \%$ ), hard blocks in the material are in form of separate structural units and aggregates. The uninterrupted (connected) network, which consists predominantly from elastic oligoether blocks with low glass transition temperature, cannot withstand external influence. That is why low values of the conditional tensile strength, elastic modulus and softening temperature are observed in this concentration range (Fig. 3). High values of the residual elongation, relative elongation and the coefficient of mechanical hysteresis losses can be explained by the low stability of the microphase of elastic blocks to mechanical stresses and, consequently, by high contribution of irreversible deformations in the scattering of mechanical energy [8].

In case of a further increase in $\mathrm{P}_{\mathrm{c}}$ (the values of about $30 \mathrm{wt} . \%)$, there is either an explicit inflection or optimum observed for most of the graphic dependencies. Thus, the values of conditional strength at tension, hardness and softening temperature increase rapidly, the value of residual elongation decreases rapidly and the values of relative elongation at rupture and the coefficient of mechanical hysteresis losses $(\chi)$ have a minimum (Fig. 3). Such a pattern of shown concentration dependences in this interval
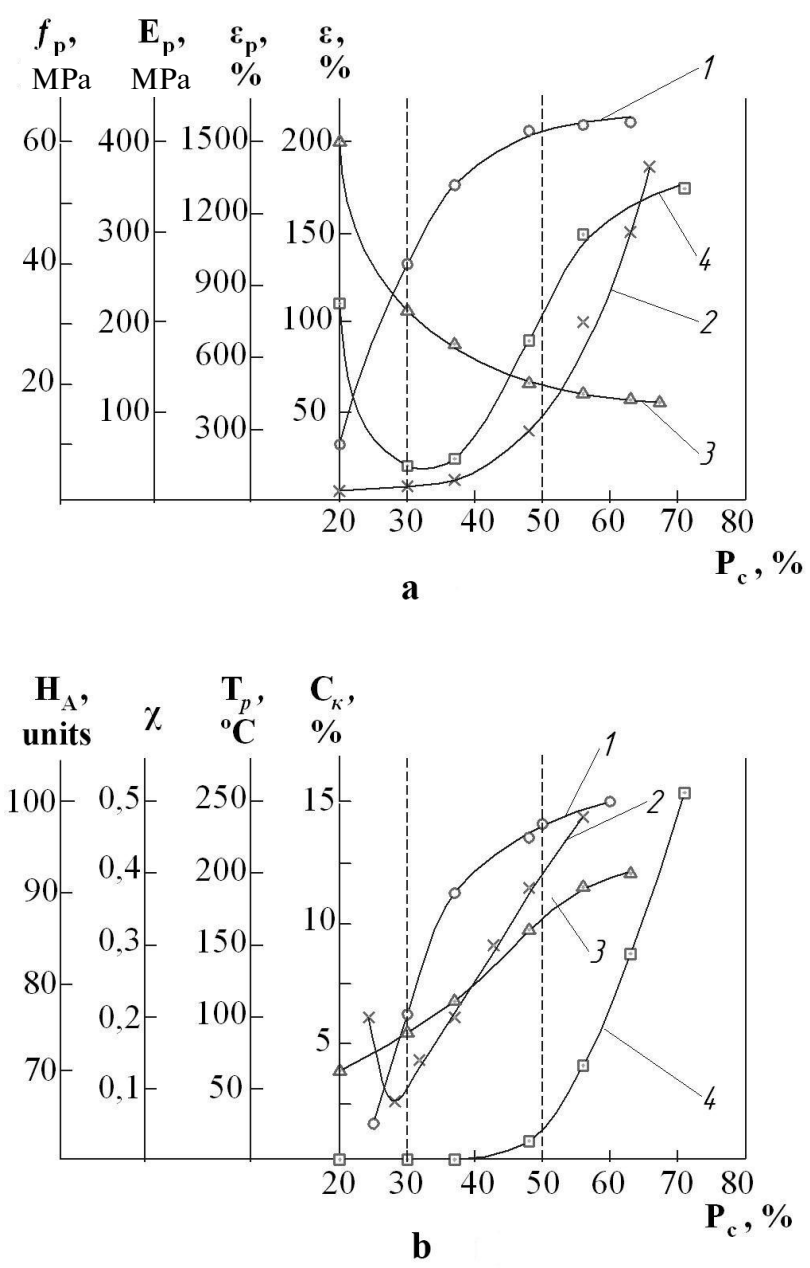

Fig. 3. Dependences of physical-mechanical characteristics of BPU based on OOTMG ${ }_{1000}$ on the content of hard blocks $\left(\mathrm{P}_{\mathrm{c}}\right)$ : $1 \mathrm{a}-$ conditional strength at tensile $\left(f_{\mathrm{p}}\right) ; 2 \mathrm{a}$ - elastic modulus

at tensile $\left(\mathrm{E}_{\mathrm{p}}\right) ; 3 \mathrm{a}-$ relative elongation at rupture $\left(\varepsilon_{\mathrm{p}}\right)$; $4 \mathrm{a}-$ residual elongation $(\varepsilon) ; 1 \mathrm{~b}-$ Shore hardness $\left(\mathrm{H}_{\mathrm{A}}\right)($ scale $\mathrm{A})$; $2 b-$ coefficient of hysteresis mechanical losses $(\chi)$;

$3 b-$ Vicat softening temperature $\left(T_{p}\right) ; 4 b-$ degree of crystallinity $\left(\mathrm{C}_{\mathrm{K}}\right)$

is likely to correspond to the moment of the appearance of a connected structure formed by the microphase of hard blocks.

At a point with $\mathrm{P}_{\mathrm{c}}$ content up to $50 \%$, some dependences show second inflection. This is typical of the concentration dependences of conditional strength at tensile), elastic modulus, relative elongation at rupture, hardness, softening temperature and degree of crystallinity (Fig. 3). This character of the above dependences indicates the appearance of a hard connected structure formed by the microphase of hard blocks. This grid of hard blocks can take the main loading and provide enhanced physical-mechanical characteristics. 
A further increase in the content of hard segments (over 50\%) leads to a more intensive growth of the elasticity modulus at tensile, degree of crystallinity, and less intensive growth of the values of conditional strength at tensile, relative elongation at rupture and hardness; residual elongation and softening temperature change insignificantly (Fig. 3).

Thus, the analysis of obtained results related to $\mathrm{BPU}$ on the basis of OOTMG $\mathrm{M}_{1000}$ allows distinguishing three following characteristic areas within which concentration dependences have significant differences: $\mathrm{P}_{\mathrm{c}}<30 \% ; 30 \% \leq \mathrm{P}_{\mathrm{c}} \leq 50 \% ; \mathrm{P}_{\mathrm{c}}>50 \%$. A noticeable inflection of all shown graphical dependences is observed at points where $\mathrm{P}_{\mathrm{cl}}=30 \%$ and $\mathrm{P}_{\mathrm{c} 2}=50 \%$. Thus, we can assume that polyurethane block-copolymers based on OOTMG ${ }_{1000}$ with $\mathrm{P}_{\mathrm{cl}}=30 \%$ can be successfully used in industry, where, first of all, it is necessary to provide high deformation characteristics. BPUs with $\mathrm{P}_{\mathrm{c}}=50 \%$ provide sufficient frame hardness under conditions of high loading and temperature influence. Undoubtedly, treatment regime of the considered BPU with different parameters of the morphological structure will significantly differ.

It should be noted that similar dependences have been established for all considered systems.

The technology of BPU processing at different temperature regimes is proposed depending on hard blocks ratio. When the temperature overcomes a certain value, the thermal destruction of BPU is possible. On average, the destruction begins at a temperature of about $220-230^{\circ} \mathrm{C}$.

The temperature interval of processing of BPU with low $P_{c}$ content is in the region of lower temperatures than that of hard BPU. It is possible to recommend the technological regimes of molding under pressure of BPU with different contents of hard blocks $\mathrm{P}_{\mathrm{c}}$, independently from the chemical nature and molecular weight of oligoglycol (Table 2).

Developed BPU can be processed into products by known methods: molding under pressure, extrusion and calendering using common equipment (Fig. 4).

For processing BPU with rational content of hard blocks, the use of screw molding machines, equipped with a single-wound three-zoned screw, is suitable. These machines provide more accurate temperature control and better homogenization of the mass.

In order to achieve optimal consumer properties of finished products from block-polyurethanes, air drying of polymer granules in dryers is recommended before processing. Moisture content in granulate should be within $0.02-0.05 \%$. The following drying parameters are recommended: 3-4 hours at the temperature of $90 \pm 5^{\circ} \mathrm{C}$.

Developed BPU can be painted using usual

Recommended regimes of molding of BPU with different content of hard blocks

\begin{tabular}{l|c|c|c}
\hline \multirow{2}{*}{ Parameter } & \multicolumn{3}{|c}{ Values } \\
\cline { 2 - 4 } & \multicolumn{3}{|c}{ Content of hard blocks, $\mathrm{P}_{\mathrm{c}}, \%$} \\
\cline { 2 - 4 } & $24-30$ & $30-50$ & $50-60$ \\
\hline Temperature of cylinder zones, ${ }^{0} \mathrm{C}$ : dosage \\
melting \\
feeding & $160-180$ & $180-190$ & $190-210$ \\
\cline { 2 - 4 } & $140-160$ & $170-180$ & $180-190$ \\
\hline Form temperature, ${ }^{0} \mathrm{C}$ & $120-140$ & $160-170$ & $170-180$ \\
\hline Injection pressure, $\mathrm{MPa}$ & $25-40$ & $25-40$ & $25-60$ \\
\hline Cycle duration, s & $40-70$ & $60-90$ & $70-110$ \\
\hline Speed of screw rotation, rpm & $30-120$ & $30-120$ & $30-120$ \\
\hline
\end{tabular}
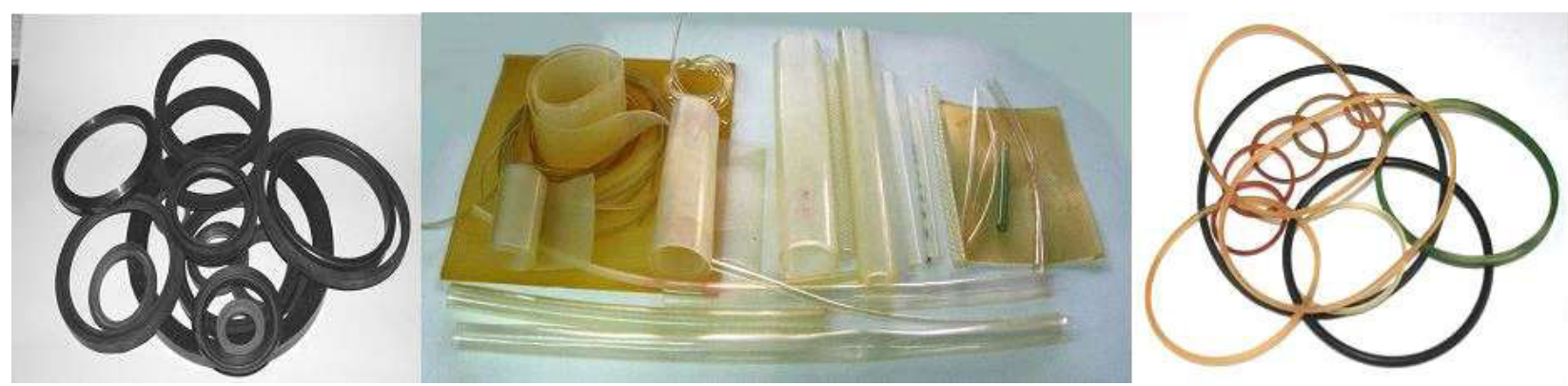

Fig. 4. Some products made of linear block-polyurethanes with different morphology 
pigments and paints which are used to paint industrial thermoplastics.

\section{Conclusions}

1. Estimation of the properties and processing regimes of BPUs in relation to hardness, which is a basis of the marking of most world manufacturers, was stated to be inaccurate and requires further research to establish the interconnection between the structure and properties of polyurethanes, taking into account their chemical structure, as well as the nature of the original components.

2. Behavior of the BPU in the ranges of the rigid phase content where $\mathrm{P}_{\mathrm{c}}<\mathrm{P}_{\mathrm{cl}}, \mathrm{P}_{\mathrm{cl}} \leq \mathrm{P}_{\mathrm{c}} \leq \mathrm{P}_{\mathrm{c} 2}$ and $\mathrm{P}_{\mathrm{c}}>\mathrm{P}_{\mathrm{c} 2}$ significantly differs. At minimum contents, when $\mathrm{P}_{\mathrm{c}}<\mathrm{P}_{\mathrm{cl}}$, the properties of the BPU are determined by the characteristics of the elastic phase (hard blocks are located in the polymer separately). At $\mathrm{P}_{\mathrm{c} 1} \leq \mathrm{P}_{\mathrm{c}} \leq \mathrm{P}_{\mathrm{c} 2}$, a structural organization is formed, in which an elastic phase with hard phase functions synergistically. At further growth of $\mathrm{P}_{c}\left(\mathrm{P}_{\mathrm{c}}>\mathrm{P}_{\mathrm{c} 2}\right)$, the properties of $\mathrm{BPU}$ are determined by the hard phase, therefore we can observe a decrease in the elasticity, an increase in the level of hardness and hysteresis losses.

3. The rational technological parameters of BPU with different phase morphology molding under pressure have been established, which allowed affecting the technological process and obtaining qualitative products.

\section{REFERENCES}

1. Byuist J.M. Kompozitsionnye materialy na osnove poliuretanov / [per. s angl. pod red. F. A. Shutova]. - M.: Khimiya, 1978. - $238 \mathrm{p}$.

2. Danylchenko D.O., Horolskyj M.S., Danylchenko O.P. Oglyad fizyko-mekhanichnykh vlastyvostei poliuretanovykh elastomeriv i perspektyvnykh galuzei ikh vykorystannya // Khimichna Promyslovist' Ukrainy. - 2001. - No. 3. - P.56-58.

3. Shtompel V.I., Kercha Y.Y. Struktura lineynykh poliuretanov - K.: Naukova dumka, 2008. -247 p.

4. Termoplastichnyi poliuretan «Vitur»: katalog / [sost. V.V. Strakhov]. - Vladimir: Tranzit-Iks, 2002. - 17 p.

5. Saunders J.H., Frish K.K. Khimiya poliuretanov. - M.: Khimiya, 1968. - 470 p.

6. Skakun J.V., Nizelskyj J.M. Termoplastychni poliuretany: budova, vlastyvosti, vykorystannja // Polimernyj Zhurnal. - 2007.
- Vol.29. - No. 1. - P.3-9.

7. Anisimov V.N. The principle of producing linear blockpolyurethane - composites of improved wear resistance // Eastern European Scientific Journal. - 2013. - No. 5. - P.107113.

8. Vliyanie molekulyarnoi massy na svoistva termoplastychnykh poliuretanov / Letunovskyj M.P., Strakhov V.V., Anysymov V.N., et al. // Plasticheskie massy. - 1987. - No. 9. - P.23-24.

9. Semenets A.A., Anisimov V.N. Development of triboengineering composite materials based on thermoplastic polyurethanes // Journal of Friction and Wear. - 2010. - Vol.31. - No. 3. - P.208-213.

Received 14.02.2019

\section{ТЕХНОЛОГІЧНІ ОСОБЛИВОСТІ ПЕРЕРОБЛЕННЯ ЛІНІЙНИХ БЛОК-КОПОЛІУРЕТАНІВ 3 РІЗНОЮ МОРФОЛОГІЕЮ}

\section{В.М. Анісімов, В.В. Анісімов}

Показана необгрунтованість оцінювання властивостей та умов перероблення поліуретанів від твердості, яка, як правило, закладена в основу їх маркування і не враховує особливостей молекулярної будови, природи вихідних компонентів. Розроблено науково обгрунтований підхід до створення матеріалів на основі блок-кополіуретанів (БПУ) з різною морфологією (вивчали вплив вмісту жорсткої фази). Встановлено характерні точки вмісту жорстких блоків $P_{c 1}$ і $P_{c 2}$, які відповідають умовам геометричних фазових переходів, виявлено умови утворення геометричної фазової морфології з оптимальними параметрами $\left(P_{c 1} \leq P_{c} \leq P_{c 2}\right)$. Так, для БПУ на основі олігоокситетраметиленгліколя в точках з $P_{c 1}=30 \%$ ma $P_{c 2}=50 \%$ спостерігається помітний геометричний перегин усіх наведених графічних залежнностей (умовної міцності при розтязі, модуля пружності, відносного видовження при розриві, твердості, температури розм'якшення, ступеня кристалічності). Встановлено технологічні параметри лиття під тиском БПУ з оптимальною фазовою морфологією, включаючи комплекси швидкого прототипування (3D принтери). Рекомендовані параметри дозволили в реальних умовах продуктивно впливати на технологічний процес лиття під тиском, одержувати якісні вироби з розроблених композитів із заданим комплексом властивостей (ущільнення, опори тертя, пружні елементи передавальних пристроїв, екструдовані джсути, кільия круглого перерізу, пластини, трубки, тощо), а завдяки реииклінгу суттєво знизити екологічне навантаження та підвищити їх комериійну привабливість.

Ключові слова: блок-кополіуретан, вміст жорстких блоків, лиття під тиском, технологічний процес, температурний режим. 


\section{TECHNOLOGICAL FEATURES OF PROCESSING LINEAR BLOCK-POLYURETHANES OF DIFFERENT MORPHOLOGY}

\section{V.N. Anisimov, V.V. Anisimov *}

Ukrainian State University of Chemical Technology, Dnipro, Ukraine

*e-mail: wwwovilon@gmail.com

We showed the inability to evaluate the properties and the processing conditions of polyurethanes based of their hardness, although such evaluation is usually used in their marking, this approach does not take into account the peculiarities of molecular structure and the nature of the initial components. A scientifically substantiated approach to the creation of materials based on blockpolyurethanes (BPU) of different morphology was developed. The effect of rigid phase content was studied. The characteristic points of the rigid blocks content, $P_{c 1}$ and $P_{c 2}$, which correspond to the conditions of geometric phase transitions, were determined and the conditions of the formation of geometric phase morphology with optimal parameters $\left(P_{c 1} \leq P_{c} \leq P_{c 2}\right)$ were found. Thus, there is a noticeable inflection in all of these graphic dependences for the BPU based on oligo(tetramethylene ether) glycol at points with $P_{c I}=30 \%$ and $P_{c 2}=50 \%$ (conditional strength at tension, elasticity modulus, relative elongation at rupture, hardness, softening temperature, and degree of crystallinity). The technological parameters of BPU molding under pressure with optimal phase morphology, including rapid prototyping complexes (3D printers), have been established. The recommended parameters allowed productively affecting the process of molding under pressure and preparing qualitative products from the developed composites with a specified complex of properties (gaskets, friction supports, elastic elements of gearing devices, extruded strands, circular rings, plates, tubes, etc.). In addition, due to recycling, we managed to substantially reduce ecological risk and increase the commercial attractiveness.

Keywords: block-polyurethane; hard block content; molding under pressure; technological process; temperature regime.

\section{REFERENCES}

1. Byuist J.M., Kompozitsionnye materialy na osnove poliuretanov [Composite materials based on polyurethanes]. Khimiya, Moscow, 1978. 238 p. (in Russian).

2. Danylchenko D.O., Horolskyj M.S., Danylchenko O.P. Oglyad fizyko-mekhanichnykh vlastyvostei poliuretanovykh elastomeriv i perspektyvnykh galuzei ikh vykorystannya [Review on physical-mechanical properties of polyurethane elastomers and promising areas of their usage]. Khimichna Promyslovist' Ukrainy, 2001, no. 3, pp. 56-58. (in Ukrainian).

3. Shtompel V.I., Kercha Y.Y., Struktura lineinykh poliuretanov [Structure of linear polyurethanes]. Naukova Dumka, Kyiv, 2008. 247 p. (in Ukrainian).

4. Strakhov V.V., Termoplastichnyi poliuretan «Vitur»: katalog [Thermoplastic polyurethane «Vitur»: a catalogue]. TranzitIks Publishers, Vladimir, 2002. 17 p. (in Russian).

5. Saunders J.H., Frish K.K., Khimiya poliuretanov [Chemistry of polyurethanes]. Khimiya, Moscow, 1968. 470 p. (in Russian).

6. Skakun J.V., Nizelskyj J.M. Termoplastychni poliuretany: budova, vlastyvosti, vykorystannya [Thermoplastic polyurethanes: structure, properties, and usage]. Polimernyi Zhurnal, 2007, vol. 29, no. 1, pp. 3-9. (in Ukrainian).

7. Anisimov V.N. The principle of producing linear blockpolyurethane - composites of improved wear resistance. Eastern European Scientific Journal, 2013, no. 5, pp. 107-113.

8. Letunovskyj M.P., Strakhov V.V., Anysymov V.N. Vliyanie molekulyarnoi massy na svoistva termoplastychnykh poliuretanov [Influence of molecular weight on the properties of thermoplastic polyurethanes]. Plasticheskie Massy, 1987, no. 9, pp. 23-24. (in Russian).

9. Semenets A.A., Anisimov V.N. Development of triboengineering composite materials based on thermoplastic polyurethanes. Journal of Friction and Wear, 2010, vol. 31, pp. 208-213. 